\title{
AEROBIC EXERCISE ON BODY MASS INDEX (BMI) CHANGE IN PERSON WITH OVERWEIGHT AND OBESITY
}

\author{
(Latihan Aerobik Terhadap Perubahan Indeks Massa Tubuh (IMT) \\ pada Individu Overweight dan Obesitas)
}

\author{
Muriyati, Patima, A. Suswani \\ Nursing Program, Stikes Panrita Husada Bulukumba \\ E-mail:patimakpr@yahoo.com
}

\begin{abstract}
ABSTRAK
Pendahuluan. Senam aerobik merupakan salah satu jenis exercise yang meningkatkan oksidasi asam lemak sehingga dapat menurunkan berat badan. Tujuan penelitian ini adalah mengetahui pengaruh latihan aerobik terhadap perubahan indeks massa tubuh (IMT) pada individu obesitas. Metode. Penelitian ini adalah penelitian quasi eksperimental dengan menggunakan pre-post test design. Individu dengan obesitas/overweight dilakukan latihan aerobik selama 3 kali dalam seminggu selama 6 minggu. Sebelum dilakukan latihan aerobik, dilakukan pengukuran Indeks Massa Tubuh (IMT) dan selanjutnya setelah latihan aerobik dilakukan pengukuran kembali Indeks Massa Tubuh (IMT). Jumlah sampel yang diteliti sebanyak 30 orang perempuan yang berumur antara umur 17-22 tahun. Hasil. Hasil penelitian menunjukkan bahwa skor IMT sebelum intervensi latihan aerobik rerata 27,54 dan rerata IMT responden setelah mengikuti senam aerobik selama 6 minggu adalah 26,65 dengan nilai probabilitas $(p=0,000)$ lebih kecil dari $(p=0,05)$, yang artinya bahwa ada pengaruh latihan aerobik dengan perubahan IMT. Diskusi. Kadar IMT telah mengalami perubahan secara signifikan setelah dilakukan latihan aerobik selama 6 minggu.
\end{abstract}

Kata kunci: IMT, aerobik, obesitas

\section{ABSTRACT}

Introduction. Aerobic Gymnastics is one type of exercise that increases fatty acid oxidation so that can lose weight. The purpose of this study was to determine the effect of aerobic exercise on body mass index (BMI) changes in person with obesity. Methods. This study was a quasi-experimental study using a pre-post test design. Individuals with obesity/ overweight do aerobic exercise for 3 times a week for 6 weeks. Before aerobic exercise, the body mass index (BMI) measured and then after aerobic exercise done reassess the Body Mass Index (BMI). The number of sample studied were 30 women aged between 17-22 years old. Results. The results showed that BMI scores before aerobic exercise intervention is average of 27.54 and the average BMI of the respondents after attending aerobics for 6 weeks was 26.65 with a probability value $(p=0.000)$ smaller than $(p=0.05)$, which means that there is effect of aerobic exercise with BMI change. Discussion. BMI levels have changed significantly after aerobic exercise for 6 weeks.

Keywords: BMI, aerobic, obesity

\section{INTRODUCTION}

World Health Organization (WHO) estimates approximately one billion men are overweight $\left(\right.$ BMI $\left.>25 \mathrm{~kg} / \mathrm{m}^{2}\right)$ and approximately 300 million men are defined as obese $\left(\mathrm{BMI}>30 \mathrm{~kg} / \mathrm{m}^{2}\right)$. Furthermore, WHO said that more than 1.4 billion adults over the age of 20 years are overweight and at least 2.8 million adults die as a result of obesity. Where $44 \%$ of them had diabetes, $23 \%$ had heart disease, ischemic, $7-41 \%$ had cancer that all caused by obesity (WHO, 2013).

In Indonesia, the National Health Research study (Riskesda) reported an increase in the national prevalence of obesity (a combined category of overweight and obese) in 2010-2013 according to the sex in which men by $15 \%$ in 2010 increased to $20 \%$ in 2013 , and by female type in 2010 increased by $26 \%$ to $35 \%$ in 2013 . The highest prevalence of overweight and obesity in the province of North Sulawesi (37.1\%), and the lowest was 13.0 percent in the province of East Nusa Tenggara. (Department of Health, 2010 and 2013).

Obesity is caused by an imbalance in the consumption of calories compared to expenditures. Calories derived from food, while it expenditure through the $\mathrm{x}$ activity of body and exercise. The amount of basic caloric 
need was determined by genetic or hereditary. However, physical activity and exercise can increase the amount of calorie expenditure. So the calorie imbalance can be determined by heredity but triggered by lifestyle and environment. Casual living habits, lazy move, always assisted by others and overeating will improve outcomes and lower calorie intake. Several studies have shown or identified the lifestyle, socioeconomic status, excessive energy consumption, low levels of physical activity as a risk factor for the development of CHD in adult people. The important of exercise (sports) regularly to prevent CHD in adolescents and adults is unclear.

When the large and growing number of fat cell multiplies in a person's body, the size of the fat cells will increase and then multiply the numbers anyway, this is what happens on the condition of obesity. Weight loss is an accumulation of abnormal or excessive fat that is likely to cause adverse effects on one's health. The Size of overweight in body mass index (BMI) $23-24.9 \mathrm{~kg} / \mathrm{m}^{2}$ and obese of BMI $25-30 \mathrm{~kg} / \mathrm{m}^{2}$ has become an epidemiology in developed country. For the current number of people worldwide with a BMI of $30 \mathrm{~kg} / \mathrm{m}^{2}$ is expected to exceed 250 million people, or about $7 \%$ of the adult population in the world (Sugondo, 2009).

Overweight or obese is a public health problem in the United States and as well as all the world's industrialized countries. In America two-thirds of the population had this experience (Galletta, 2012). Similarly the prevalence of overweight in Indonesia itself is still high. There are many ways in which to reduce weight problems one of which is to do aerobic exercise. Aerobic physical exercise is known to be good for weight loss because it uses bigger calories and helps to increase metabolism and help the body burn calories faster. Aerobic exercise is an effective way to lose fat if it is done regularly.

Based on these descriptions, the researcher is interested to see the effect of aerobic exercise on body mass index (BMI) changes. The purpose of this study was to determine the effect of aerobic exercise on BMI in person with overweight and obesity.

\section{METHODS}

This study was a pre-experimental studies or pre-experimental design (Quasiexperimental). The study design used the one-group pre-posttest design. In this study selected a group of subjects or experimental units. Before the treatment, conducted measurements (pre-test) and then given treatment and at the end of the activity or after the treatment, then reassess (post-test). The population in this study was 80 female nursing students of Akper Anging Mammiri, Akper Muhammadiyah Makassar, and Akbid Muhammadiyah. Determination of the number of samples for this study is using the method of purposive sampling that all were categorized as the target population and affordable population and meet the inclusion and exclusion criteria. The number of samples in the study was 35 students. This study conducted in OctoberSeptember 2014 in Balai kesehatan olahraga masyarakat (BKOM) Makassar.

Data were analyzed by univariate and bivariate to determine the effect of aerobic activity on weight loss. To see the effect of aerobic exercise variables on levels of fat and fat composition profile by using the Wilcoxon test.

\section{RESULT}

Table 1. Distribution of Respondents with an Average of Obese and Overweight Individuals Based on Characteristics of Height $(\mathrm{N}=30)$

\begin{tabular}{lccc}
\hline Variable & Mean & SD & Min-Max \\
\hline Height & 154,9 & 4,67 & $143-168$ \\
\hline
\end{tabular}

Table 2. Distribution of the Average Respondent to Obesity and Overweight based on The Characteristics of Body Weight $(\mathrm{N}=30)$

\begin{tabular}{lccc}
\hline \multicolumn{1}{c}{ Variable } & Mean & SD & $\begin{array}{c}\text { Min- } \\
\text { Max }\end{array}$ \\
\hline Scoreof BWpre & 66,30 & 14,17 & $54-120$ \\
Score of BWpost & 64,03 & 14,01 & $51-118$ \\
Deficient of mean & 2,27 & & \\
\hline
\end{tabular}


Table 3. Distribution of Average Respondents with Obesity and Overweight based on BMI Scores Before and After The Intervention $(\mathrm{N}=30)$

\begin{tabular}{lccc}
\hline \multicolumn{1}{c}{ Variable } & Mean & SD & $\begin{array}{c}\text { Min- } \\
\text { Max }\end{array}$ \\
\hline Score of BMI pre & 27,54 & 4,67 & $23-43$ \\
Score of BMI post & 26,65 & 4,75 & $22-42$ \\
Deficient of mean & 0,89 & & \\
\hline
\end{tabular}

23 people (73\%). The average value score of weight respondents after the intervention was lower (64.03) than the value of the average score of body weight before the intervention (66.30). From the results of the aerobic exercise intervention showed that there was a deficient scores change in body weight before and after intervention to be 2.27 points.

Table 4. Distribution of Average Respondents with Obesity And Overweight based on BMI Scores Change Before and After The Intervention $(\mathrm{N}=30)$

\begin{tabular}{lcccc}
\hline \multirow{2}{*}{ Changes } & \multicolumn{2}{c}{ Overweight } & \multicolumn{2}{c}{ Obesity } \\
\cline { 2 - 5 } & Amount (n) & Percentage (\%) & Amount (n) & Percentage (\%) \\
\hline Increase & 3 & 21 & 2 & 11 \\
Decrease & 10 & 71 & 12 & 67 \\
Stabile & 1 & 7 & 2 & 11 \\
Amount (n) & 14 & 100 & 16 & 100 \\
\hline
\end{tabular}

Table 5. Analysis Differences of BMI Scores Before and After Intervention $(\mathrm{N}=30)$

\begin{tabular}{lcccc}
\hline \multicolumn{1}{c}{ Variable } & Mean & SD & Min-Max & Value of $\boldsymbol{p}$ \\
\hline Score of BMIpre & 27,54 & 4,67 & $23-43$ & $0,000^{*}$ \\
Score of BMI post & 26,65 & 4,75 & $22-42$ & \\
Deficient of mean & 0,89 & & & \\
\hline
\end{tabular}

*Wilcoxon Test

Table 6. Frequency Distribution of Respondents based on Changes in BMI Scores After Intervention $(\mathrm{N}=30)$

\begin{tabular}{lcc}
\hline \multicolumn{1}{c}{ Variable } & $\begin{array}{c}\text { Amount } \\
(\mathbf{n})\end{array}$ & $\begin{array}{c}\text { Percentage } \\
(\mathbf{\%})\end{array}$ \\
\hline Score Stabile & 2 & 10 \\
Score Decrease & 23 & 73 \\
Score Increase & 5 & 17 \\
\hline
\end{tabular}

Table 1 above showed that the average respondent has a height 154.9 centimeters $(\mathrm{cm})$. Where the minimum height was $143 \mathrm{~cm}$ and the maximum height was $168 \mathrm{~cm}$. The average value of BMI scores prior to the intervention (27.54) different from the average value of BMI scores after the intervention (26.65) with the deficient of meanis 0.89 . This was evidenced by the results of statistical tests in table 5, which shows the value of $p=0.000$. In addition, analysis of the frequency distribution in Table 6 showed that BMI scores decreased in the majority of respondents as many as
The average value of BMI scores of respondents after the intervention was lower (26.65) than the average value of BMI scores before the intervention (27.54). From the results of the aerobic exercise intervention showed that there was a deficient scores change of BMI scores before and after the intervention to be 0.89 points. Analysis of the frequency distribution in Table 4 shows that the most decreased BMI scores are in overweightcategory as many as $10(67 \%)$ while the most increasing also in the overweight category by $3(11 \%)$.

\section{DISCUSSION}

\section{Relationship of Aerobic Exercise with Body Mass Index (BMI)}

The results of this study indicated that BMI scores before aerobic exercise intervention mean of 27.54 and a mean BMI of the respondents after attending aerobics for 
6 weeks was 26.65 with a probability value ( $p$ $=0.000)$ smaller than $(p=0.05)$, which means that there was the influence of aerobic exercise with changes in BMI. Where there were 23 respondents who experienced a decrease in BMI, 5 respondents experienced an increase in $\mathrm{BMI}$, and 2 respondents with a stabile BMI.

The results were consistent with the research that has been done by Patrilasni which revealed that aerobic exercise can reduce weight by $17.36 \%$ of individuals who carried for 12 weeks. Sientia (2012) also said that there is a significant change in body weight $(\mathrm{p}=0.000)$ in participants before and after aerobic exercise for 12 weeks at a fitness club with a mean initial weight $59.8 \pm 9.49$ participants and the average of final weight was $56.9 \pm 8.72$ participants.

Utomo (2012) also explained that physical exercise is more effective for weight loss as compared with other interventions. Aerobics exercises proved weight loss of $66.78 \%$, percentage of body fat is $86.42 \%$, and cholesterol as many as $27.67 \%$. The conclusion that there is a significant effect of low impact aerobic exercises on weight loss, the percent of body fat and cholesterol levels in adolescent girls with obesity.

Tengadi (2010) said that the cardiorespiratory system during exercise or when a person is exercising regularly carrying the oxygen and nutrients to the muscles. $\mathrm{He}$ said also that the chance of a good aerobic will result in cardiac output or the ability to pump blood throughout the body becomes better example when we run/jog the cells become more active and thus require more oxygen this means that the body requires more blood flow to the cells per minute.

The higher a person's BMI would result in the load of heart and also increases to pump blood and nutrients to the tissues of the body per minute, or in other words increasing the cardiac output. The cardiac output increases proportionally with the increase in body surface area, volume value is expressed in cardiac output per square meter of body surface area known as the cardiac index so that the excess BMI decrease cardiorespiratory endurance that impact on reducing mileage run for 12 minutes (Herman, 2010)

Sports require muscle contraction formed from adenosine triphosphate (ATP). The formation of ATP is derived from glucose metabolism in aerobic and anaerobic, but rarely obtained from protein. Aerobic metabolism which consumes oxygen better since ATP is produced more efficiently in an aerobic.

Sports are good for weight losses in people who are obese or overweight are aerobic exercise, moderate intensity with a frequency of $\geq 3$ times per week. The more physical activity, calories burned will also be increasingly used as energy in losing weight (CDC, 2011). If calorie intake is restricted, then the combination of physical activity and a decrease in the amount of calories eaten cause a "calorie deficit" that would eventually lead to weight loss (CDC, 2011). In this study, respondents had undergone calorie restriction and it also plays a role in the weight loss process of respondent's BMI. In Table 6 shows that there are two $(10 \%)$ of respondents with a stabile BMI and $5(17 \%)$ of respondents who had a BMI increase, it is thought to be caused due to the ineffectiveness of the respondents in the calorie restriction.

Sherwood (2001) stated that aerobic exercise is a form of physical activity involving large muscles and conduct in a fairly low intensity as well as in a long time. Aerobic exercise is physical activity that is designed separately increases oxygen consumption and improve the function of the respiratory system and cardiovascular system. Aerobic exercise is conducted with the aim to improve cardiovascular endurance and to lose weight. This kind of sport is highly recommended in people who are obese or overweight (Sherwood, 2001)

Aerobic exercise or commonly called cardiovascular exercise increases the work function of the lungs, heart and blood circulation, so that the body gets better and use oxygen for cellular metabolism. Oxygen functions in the formation of the body's energy source, namely adenosine triphosphate (ATP) using citric acid cycle as a major metabolic pathway (Sherwood, 2001). 
Other studies claim that the correlation between BMI and physical fitness of college women in Seoul, which states significantly negative correlation, the big BMI decreasing physical fitness in 158 college women (Hye NB et al, 2003).

\section{CONCLUSION}

BMI levels have undergone significant changes after aerobic exercise three times a week for 6 weeks. It is concluded that regular aerobic exercise can cause changes in BMI individuals with overweight and obesity.

\section{RECOMMENDATIONS}

There are many factors that can influence the BMI in individuals with obesity and overweight, such as heredity and also triggered by lifestyle, environment and hormones. In studies conducted in Japan found subjects with the GG genotype had lower plasma adiponectin levels than the TT genotype. The odds ratio in this condition was more than 2. Another thing that was found that plasma adiponectin concentration was lower in obese subjects. The Mechanism that underlying the decrease plasma adiponectin concentration is not clear, one of which is the inhibition of the synthesis and secretion of tumor necrosis factor-alpha (TNF-alpha), which is produced locally in large numbers on viceral obesity, starting with the entry of macrophages into adipose tissue. Under these conditions, the researchers were able to develop this research by looking at the role of genes polimerfisme adiponectin and adiponectin levels of BMI individuals with obesity.

\section{REFERENCES}

Departemen kesehatan, 2013, Riset kesehatan dasar (RISKESDA)

Galletta GM. 2012. Obesity. eMedicine Health, expert of everyday emergencies. Available at: http://www.emedicine health.com/obesity/article_em.htm (diak-ses tanggal 12 Januari 2012)

Herman RB. Buku ajar fisiologi jantung. Jakarta: Buku kedokteran EGC. 2010.

Hye NB, Hyun KJ, Kyung CS. Correlation between BMI and physicalfitness of college women in Seoul. Journal Community Nutrition. 2003; 5: 29-36.

Sientia Fathirina, 2012 Pengaruh Latihan Senam Aerobik Terhadap Perubahan Berat Badan Pada Peserta Klub KebugaranStudi Kasus Di Klub Kebugaran Susan, Semarang Jurnal Media Medika Muda Fakultas Kedokteran Universitas Diponegoro

Sherwood L. (2001). Fisiologi Manusia dari Sel ke Sistem. Jakarta: Penerbit Buku Kedokteran EGC

Sugondo S, Obesitas. Buku Ajar Ilmu Penyakit Dalam Jilid III. Edisi V. Jakarta. Interna Publishing. 2009. Hal: 1973-83

Tengadi KA. Fisiologi olahraga. Dalam: Guyton AC, editor. Buku ajar fisiologi kedokteran. Edisi 7 bagian III. Jakarta: EGC. 2001. hal. 374-87.

Utomo GT, dkk, 2012 Latihan Senam Aerobik Untuk Menurunkan Berat Badan, Lemak, Dan Kolesterol,Jurusan Ilmu Keolahragaan, Fakultas Ilmu Keolahragaan, Universitas Negeri Semarang, Indonesia.

WHO Department of Nutrition for Health and Development, 2013, Obesity and overweight 